\title{
Assessment of Barriers to Knowledge and Experience Transfer in Major Maintenance Activities
}

\author{
Lilian. O. Iheukwumere-Esotu $(1)$ and Akilu Yunusa Kaltungo *(1) \\ Department of Mechanical, Aerospace and Civil Engineering, The University of Manchester, Oxford Rd, \\ Manchester M13 9PL, UK; lilian.iheukwumereesotu@manchester.ac.uk \\ * Correspondence: akilu.kaltungo@manchester.ac.uk
}

Received: 13 March 2020; Accepted: 1 April 2020; Published: 4 April 2020

Abstract: Systematic failure analysis generally enhances the ability of engineering decision-makers to obtain a holistic view of the causal relationships that often exist within the systems they manage. Such analyses are made more difficult by uncertainties and organisational complexities associated with critical and inevitable industrial maintenance activities such as major overhauls, outages, shutdowns, and turnarounds (MoOSTs). This is perhaps due to the ratio of tasks-to-duration typically permitted. While core themes of MoOSTs including planning, contracts, costing, execution, etc., have been the focus of most research activities, it is worth noting that the ability to successfully transfer and retain MoOSTs knowledge is still under-investigated. Effectively implementing a case study-based approach for data collection, the current study explores the harmonisation of various risk assessments (i.e., fault tree analysis and reliability block diagrams) and multicriteria decision analysis (MCDA) tools to investigate perceived barriers to MoOSTs knowledge management and experience transfer. The case study selected for this study is a dual process line all-integrated cement manufacturing plant (the largest of such process configuration in its region). The justification for this choice of industry was driven by the volume and frequency of MoOSTs executed each year (typically $4-1$ per process line), thereby providing a good opportunity to interact with industrial experts with immense experience in the management/execution of MoOSTs within their industry. A multilayered methodology was adopted for information gathering, whereby baseline knowledge from an earlier conducted systematic review of MoOSTs practices/approaches provided fundamental theoretical trends, which was then complemented by field-based data (from face-to-face interviews, focus group sessions, questionnaires, and secondary information from company MoOSTs documentation). During the analysis, fault tree analysis (FTA) and reliability block diagrams (RBDs) were simultaneously used to generate the causal relationships and criticality that exist between identified barriers, while the MCDA (in this case analytical hierarchy process) was used to identify and prioritise barriers to MoOSTs knowledge management and experience transfer, based on sensitivity analysis and consistency of approach. The primary aim of this study is to logically conceptualise core barriers/limiters to knowledge in temporary industrial project environments such as MoOSTs, as well as enhance the ability of decision-makers to prioritise learning efforts. The results obtained from analysis of data identify three major main criteria (barriers) and 23 subcriteria ranked according to level of importance as indicated from expert opinions.

Keywords: industrial maintenance management; failure analysis; knowledge management; multicriteria decision analysis; major overhauls-outages-shutdowns-turnarounds

\section{Introduction}

The dynamic nature of new economies over the past two decades has created competitive environments among companies, compelling consolidation of existing knowledge assets as pathways 
to creating value $[1,2]$. The most pressing needs identified by different studies on how firms can compete effectively is the ability to identify different types of knowledge existing within, utilizing these existing knowledge, and in turn developing them to create new knowledge and capabilities [3]. The need to create and add value has presented new waves of challenges for the maintenance department in continuous production and/or operational industries such as power, manufacturing, process, aerospace, defence, etc. These types of industries heavily depend on a distinct type of large scale maintenance activities performed at an instance known as, major overhauls, outages, shutdowns, and turnarounds (MoOSTs) for smooth running of physical assets [4,5]. For instance, in oil and gas plants, MoOSTs are the largest maintenance activities in terms of criticality, cost, and time [5]. The significance of MoOSTs expenditures on maintenance organisations budgets' becomes ominous when considered that $80 \%$ of such MoOSTs related activities sometimes exceed their costs by approximately $10 \%-40 \%$ [6]. In an attempt to contextualize the criticality of MoOSTs, [7] reckoned that $35 \%-52 \%$ of industrial maintenance budgets are expended on planning and execution of MoOSTs. Similarly, MoOSTs in the energy sector is often tagged the costliest and most tedious industrial activity. This perhaps owing to the fact that virtually all sectors rely on energy to function, hence the need for routine and thorough plant improvement initiatives through extensive MoOSTs. Additionally, recent population growth trends across the globe is creating sharp disparities between energy supply and demand. In addition to capital-intensive capacity expansions, which are quite crucial, another vital means of keeping up with increasing power demand is for existing energy systems worldwide to constantly operate around their installed capacities. Based on this premise, critical maintenance interventions such as MoOSTs will need to be executed under even more stringent time and cost constraints in the immediate future, thereby making it imperative to harness all knowledge and experience to aid success.

Although there are studies within the current body of knowledge that capture knowledge management barriers in project management, the peculiarities and specific requirements of MoOSTs listed in $[8,9]$, dictates a need to present an approach for assessing barriers to knowledge management with emphasis on acquisition and transfer of staff experiences (tacit knowledge) specifically developed for managing MoOSTs. Consequently, there are evidences supporting arguments that favour unique approaches to sharing knowledge and experience transfer within projects, which depend heavily on social practices and patterns in organisations [10]. This is because, based on what has been learnt from different studies on managing tacit knowledge, particularly on areas concerned with surmounting the challenges of developing frameworks that can aid expression and sharing of subjective experiences, insights and intuitions of individuals, as well as groups in organisations [11]. Furthermore, existing project management based studies, $[3,12,13]$ have focused on identifying and reviewing potential knowledge sharing barriers within organisations and project environments, which although useful in order to provide a comprehensive and structured starting point for effective audit systems, do not present a holistic approach for knowledge management and experience transfer in MoOSTs.

However, there are few studies that have recognised the need for an enhanced knowledge management system within MoOSTs supply chains [14]. The focus of most of these studies being on lagging indicators, which are mostly for the purpose of information management but as useful as these lagging indicators are in their ability to measure predetermined outputs, their ability to support prognosis and sustainable experience management are quite limited. Moreover, while reviewing the literature on methodologies adopted to address challenges of knowledge management and experience transfer in MoOSTs environments, it was observed that the use of hybrid engineering failure analysis approaches such as, fault tree analysis (FTA), reliability block diagrams (RBDs) alongside multicriteria decision analysis (MCDA) techniques (e.g., analytical hierarchy process (AHP)) is scant. Although few references in literature exist of studies that have implemented MCDA techniques to evaluate critical qualitative and quantitative factors in MoOSTs. Take for instance, [15] examined process quality, quality of machinery, quality of project team, and output quality and [16], conducted a research on preselecting contractors based on safety criteria for MoOSTs using AHP. Perhaps [17] is one study which has highlighted possible areas in the entire MoOSTs supply chain that can benefit from learning 
and improvement through collective rankings and prioritisations of stakeholders requirements using the quality function deployment (QFD) tool which can be integrated into AHP. However, these articles barely identified specific barriers facing MoOSTs knowledge management and experience transfer but focused on activities that encourage information management rather than deep learning acquired through experience which is basis for this study.

Therefore, in light of these gaps in the body of knowledge, the identification and ranking of barriers to knowledge management and experience transfer in MoOSTs is pertinent, and it has also become necessary to demonstrate the effectiveness of utilising engineering failure analysis approaches alongside MCDA techniques for addressing this challenge in the context of MoOSTs. This study will follow an approach of exploring several questions which are addressed to experts through a field study:

1. What are the barriers to knowledge management and experience transfer in MoOSTs?

2. Do the identified barriers contribute equally to failure of the entire knowledge management system or could their casual effects be prioritised based on significance of impact?

3. Are these barriers specific to MoOSTs or do they equally affect other engineering projects?

The main objectives are, to identify, as well as, rank barriers to knowledge management and experience transfer based on perceptions of experts who have significant involvements in MoOSTs. The aim is to establish a road map for further work on this subject that can potentially lead to selection of appropriate solutions (alternatives) that would spur developments of knowledge management and experience transfer frameworks. This is particularly useful because, harnessing knowledge and experience domiciled within individuals in MoOSTs organisations is an important asset that can enhance the ability of a company to sustainably attain its underlying strategic business goals. Therefore, integration and application of methods such as, FTA, RBD, and AHP are demonstrated through a case study approach to assess the barriers of knowledge management and experience transfer in MoOSTs.

\section{Materials and Methods}

Relevant studies $[18,19]$ have argued that organisations can most likely learn more from failure than from success, which is perhaps due to success leaving an impression of great achievements which do not result in deep learning. Failure on the other hand produces a despondent reaction within the organisation, but if properly managed, might lead to identification of probable root causes which could in turn lead to accountability. The use of engineering failure analysis approaches to investigate probable/possible root causes of failures are quite common in literature, most notably the use of popular techniques such as fault tree analysis (FTA) and reliability block diagrams (RBDs) to model failures. A study by [20] employed these techniques (i.e., FTA and RBD) to detect the causal factors, as well as their interrelations for a chronic cement plant rotary kiln refractory brick failure, so as to provide detailed dimension of vulnerabilities in maintenance, operations, and quality practices. While [21] and [22] also used both FTA and RBD techniques for analysing historic engineering catastrophes such as Fukushima nuclear disaster (2011), BP Texas city incident (2005), NASA's space shuttle Columbia accident (2003), Chernobyl disaster (1986), Bhopal disaster (1984), and sinking of the Titanic Ocean liner (1912).

Furthermore, the integration of multicriteria decision-making (MCDM) methods such as analytical hierarchy process (AHP) with other risk assessment techniques such as FTA and RBD to provide a hybrid solution model is also very popular in literature. According to [23], the use of a single technique has limited capacity to represent complex realities. This is in contrast with the use of MCDAs that can facilitate development of hierarchy of problems, selection of alternatives, and allocation of values, as well as preferences elicited from participants in a group [24,25]. Demonstration of the merits of hybrid models for failure investigation within the aviation industry was also studied, using accident reports obtained from the Directorate of Accident Investigation [26]. The study [26] adequately exposed frailties within existing frameworks, particularly the decision-making facets and was adjudged to significantly contribute to recent catastrophes. 


\subsection{Theoretical Framework}

\subsubsection{Overview of the Fault Tree Analysis Technique}

FTA is a top down deductive method that translates physical systems into logical diagrams, showing how equipment failure, human error, and/or external factors can influence an event [27]. Since it was first used in the aerospace industry, it has become an increasingly popular method for people involved in reliability and safety calculations and has extended to industries such as nuclear, power, and chemical processing [28,29]. The construction of a fault tree (FT) involves the systematic breakdown of the factors leading to an undesirable event within a system into source events, through the application of gate symbols to structure cause and effect relationships of failures [30]. The top events in the FTA are usually indications of failures of major consequences, which could endanger human lives or lead to significant economic losses. The bottom or basic events are used to determine the root causes. FTs are capable of yielding quantitative and qualitative information about a system, and are particularly useful for providing better understanding of potential causes of failures that can lead to a rethink of approaches to eliminate or reduce potential hazards within the system. However, a major limitation of this technique is that its success could be influenced by the investigation team's familiarity with the topic, thereby embedding some elements of human subjectivity [21]. Typical gate symbols used in FTA and their meanings are given in Table 1.

Table 1. Common fault tree analysis (FTA) gate symbols and their descriptions [27].

\begin{tabular}{|c|c|c|}
\hline Fault Tree Symbol & Meaning & Description \\
\hline & AND (Parallel) & $\begin{array}{c}\text { Requires the occurrence of all input events for a } \\
\text { resulting output event. }\end{array}$ \\
\hline & OR (Series) & $\begin{array}{l}\text { Requires occurrence of any single event for a } \\
\text { resulting output event. }\end{array}$ \\
\hline & Intermediate event & Resulting event of different interacting events. \\
\hline & Basic event & The least event that cannot be further defined. \\
\hline
\end{tabular}

\subsubsection{Overview of Reliability Block Diagram Technique}

RBD is a method based on representing a system by interconnected blocks (i.e., series, parallel or combinations). The connections between individual blocks signifies the influence on the reliability of an entire system [31]. In systems' reliability analysis, a system is depicted as being in series, if it fails when one or more components fail. On the other hand, a system is depicted as parallel if only simultaneous failure of multiple components leads to system failure. RBDs are particularly concerned with different combinations of components within the system that will lead to system functionality, which is its main distinction with the FTA that solely focuses on system failure combinations [32,33]. The overarching purpose of developing equivalent RBDs is an attempt to visualise relationships of causal factors that can lead to identification of vulnerabilities and/or resilience within a system. Despite its usefulness, RBDs have been criticised for their overreliance on near perfect (which is often unrealistic in all circumstances, especially when dealing with unfamiliar problems) FT outputs in order to generate accurate results [22]. Detailed and clear guidelines for constructing RBDs, as well as their conversion to FTs and vice versa are available in [21], while [20] further demonstrates real-life implementations. Typical RBD symbols and their associated interpretations are provided in Table 2. 
Table 2. Typical reliability block diagram (RBD) symbols and their descriptions.

\begin{tabular}{ccc}
\hline \multicolumn{2}{c}{ RBD Symbol } & Meaning \\
\hline
\end{tabular}

2.1.3. Overview of Analytical Hierarchical Process (AHP) as a Multicriteria Decision Analysis (MCDA) Tool

Recent decades have experienced widespread applications of AHP [33] for analysing complex and dynamic problems involving multiple criteria (also denoted as multicriteria decision analysis). Studies such as $[24,34,35]$ have adequately explored the proficiency of AHP within a wide range of disciplines. In order to make a decision in an organised manner, [36] suggested the adoption of the following three principles: Decomposition, comparative judgement, and synthesis of priorities. The decomposition of the decision element, as well as its associated steps was also described in [36]. Subsequently, [37] recommended the application of a specific scale to support comparative judgements, which was also trialled and compared to other existing scales. Judgements are typically elicited qualitatively from people within a group/panel and then assigned appropriate values from the specified scale. The perceived weakness of AHP is often attributed to its reliance on the precision of the questions directed to selected decision-makers, thereby creating doubts about the consistency of results under different sets of questions, even if the investigated topic remains the same [35]. However, these criticisms have been adequately addressed by [37] whereby the ability of AHP to provide a flexible, systematic, and repeatable evaluation process that can be used for selecting optimal alternatives amidst multiple criteria has been shown [34]. During comparative judgements (also known as pairwise comparisons), a judgement matrix [38] is governed by Equation (1):

$$
A_{n}=\left[\begin{array}{ccccc}
. . & C_{1} & C_{2} & . . & C_{n} \\
C_{1} & a(1,1) & a(1,2) & . . & a(1, n) \\
C_{2} & a(2,1) & a(2,2) & . . & a(2, n) \\
: & : & : & \vdots & : \\
C_{n} & a(n, 1) & a(n, 2) & . . & a(n . n)
\end{array}\right]
$$

To improve consistency of judgements, reciprocals are automatically assigned to each pairwise comparison and [35] provides a clear demonstration of this approach. Upon completion of the pairwise comparison, consistency is determined by eigenvalue $\max \lambda_{\max }$, whereby the consistency index $(\mathrm{CI})$ is given as $\left(\lambda_{\max }-n\right) /(n-1)$, where $n$ is the matrix size. The test for reliability of consistency for a given reciprocal matrix is termed consistency ratio (CR) and obtained by estimating the ratio of $\mathrm{CI}$ to the average random consistency index (RI) given in Table 3. According to [38,39], a CR lower than $10 \%(0.1)$ is classified as sufficiently consistent. Table 4 shows the fundamental scale of absolute numbers. The final process of AHP involves synthesis and ranking of priorities which was manually demonstrated in this study and outcomes were compared to those obtained via transparent choice (an AHP software). The results from both estimations had very little variance. 
Table 3. Average random consistency (RI) [38,40].

\begin{tabular}{ccccccccccc}
\hline Size of Matrix & 1 & 2 & 3 & 4 & 5 & 6 & 7 & 8 & 9 & 10 \\
\hline Random Consistency & 0 & 0 & 0.58 & 0.9 & 1.12 & 1.24 & 1.32 & 1.41 & 1.45 & 1.49 \\
\hline
\end{tabular}

Table 4. Fundamental scale of absolute numbers [36-38].

\begin{tabular}{|c|c|c|}
\hline Intensity of Importance & Definition & Explanation \\
\hline 1 & Equal importance & Two activities contribute equally to the objective \\
\hline 2 & Weak or slight & - \\
\hline 3 & Moderate importance & $\begin{array}{l}\text { Experience and judgement slightly favours one } \\
\text { activity over another }\end{array}$ \\
\hline 4 & Moderate plus & - \\
\hline 5 & Strong importance & $\begin{array}{l}\text { Experience and judgement strongly favours one } \\
\text { activity over another }\end{array}$ \\
\hline 6 & Strong plus & - \\
\hline 7 & Very strong & $\begin{array}{l}\text { An activity is favoured very strongly over } \\
\text { another: Its dominance demonstrated in practice }\end{array}$ \\
\hline 8 & Very, very strong & - \\
\hline 9 & Extreme importance & $\begin{array}{l}\text { The evidence favouring one activity over another } \\
\text { is of the highest possible order of affirmation }\end{array}$ \\
\hline
\end{tabular}

\subsubsection{Group Decision-Making}

The application of group decision-making in AHP is an integral technique for eliciting responses which are used to generate pairwise comparisons. Participants in a group make use of their experiences, as well as values on knowledge of a particular discipline to break down specific problems into a hierarchy which are then solved by step-by-step application of the AHP process [35]. Although the Delphi technique is a popular method for achieving group decision-making as it is designed as a structured group communication process that allow individuals within a group to deal with complex problems [25], but problems of dominance still persists [34]. Group sessions that consist of experts with similar goals require adequate thoughts that can be modified to suit understanding of the problem. Recommendations on expert categorisation for building representative panels in [25] and suggestions on participants selection based on modelling of a typical Delphi survey panel [41] were integrated. Furthermore, suggestions on group size (typically 9-18 participants) in order to alleviate difficulties associated with reaching consensus among experts [34] was also adopted. Hence, the group size " $n$ " applied here was restricted to 10 participants.

\subsection{Research Methodology}

In order to assess perceived barriers to knowledge and experience transfer in MoOSTs management, a proposal to carry out the following methodology was conceived:

- Theoretical based perspectives emerged through a previously conducted systematic literature review, to provide a broad state-of-the-art review in this discipline.

- A practice-based study, was implemented to obtain responses of participants through the combination of semi-structured interviews and focus group session to employees of the case study. These covered important facets of MoOSTs (mostly extracted from the theoretical framework and internal secondary documentations domiciled at the case study).

- The group decision-making process involved identifying and selecting top level, mid-level, and lower level criteria based on values and preferences of group decision makers. Subsequently, three main top-level barriers and 23 individual basic elements were modelled using FTA. The process mimicked a modified Delphi process which involved brainstorming, 
streamlining, and ranking [42], but without the commonly encountered problems of group dominance, rather, hierarchy of problems and criticalities generated from FTs and RBDs were used to elicit responses (which aided the selection of values and preferences based on the linguistic AHP scale). The group was shown the problem at hand based on the initially prepared FTs. Group members were then requested to develop the hierarchy of problem, and responses involving allocation of linguistic AHP values (Table 4). Subsequently, preferences were then ranked from highest to lowest. The consensus judgements established after choosing 'average' of the judgement were computed manually and through 'Transparent Choice'. In a few instances, voting technique was adopted if the average was significantly skewed.

Table 5 shows the categorisation of expert skills and specific knowledge areas of participants in this specific MoOSTs case and integration of inputs from each research approach, while the entire research methodology is depicted in Figure 1. Appendix D (Table A10) provides further details of the sample sizes within each category.

Table 5. Group decision panel.

\begin{tabular}{|c|c|}
\hline Category & MoOSTs Responsibility \\
\hline A & $\begin{array}{l}\text { Middle to senior management staff directly involved with MoOSTs, who makes/approves decisions on } \\
\text { overall strategies. }\end{array}$ \\
\hline B & $\begin{array}{l}\text { Supervisory staff involved with the implementation of engineering methods and/or techniques, } \\
\text { who also has authority to make decisions during MoOSTs. }\end{array}$ \\
\hline $\mathrm{C}$ & Shop floor staff experienced with handling plant assets and schematics showing working of the plant. \\
\hline
\end{tabular}

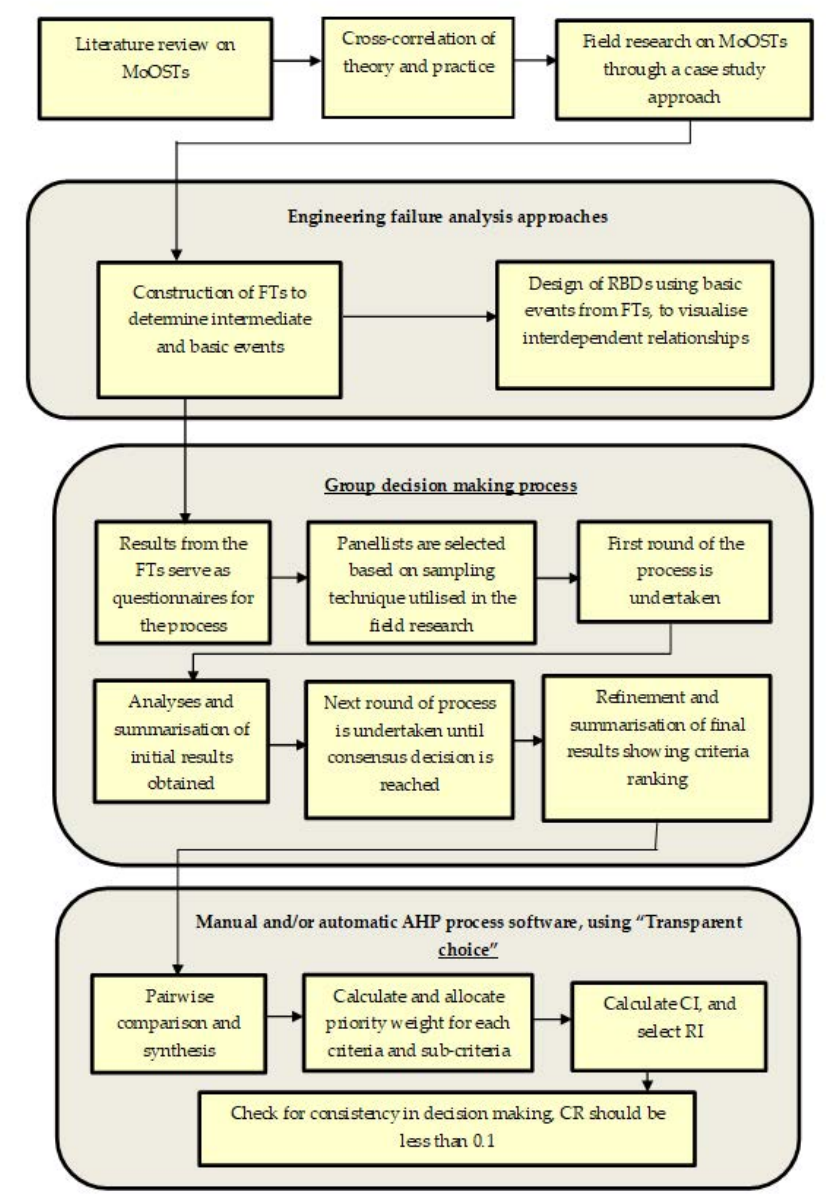

Figure 1. Schematic diagram showing integration of the entire research process. 


\section{Case Study Description}

The case study is a cement manufacturing plant in the UK which has been tagged 'ABC' company to maintain anonymity and confidentiality. Participants were company employees, and selection criteria required their involvement in an average of 15 MoOSTs. The company operations involve a $24 \mathrm{~h}$, seven days a week continuous flow processing system and transports an average of $1.45 \mathrm{~m}$ ton per year, with $1 \mathrm{~m}$ transported by rail and 450,000 by truck. Scheduled plant shutdowns for maintenance in the organisation are also referred to as major overhauls. Two of such major repairs per rotary kiln production line are scheduled annually (i.e., minimum of four rotary kiln shutdowns a year since there are two rotary kilns production lines). Cement mills and raw mills shutdowns, on the other hand, are scheduled biannually. Prefabrication and preparation of long lead time items (e.g., refractory bricks, burner, and preheater castables, etc.) could take up to 18 months, and three months is dedicated for planning. A minimum of six months interval between each subsequent shutdown occurs. Execution of main activities occurs within 26-32 days for major repairs on the kiln (e.g., replacement of shell sections, kiln alignments, etc.) and 10-14 days for major repairs on the cement and raw mills. A manpower requirement typically peaks at 200-300 people, thereby amassing over 140,000 man-hours for the shutdown duration. The justification for the selection of the cement industry as a case study was based on the premise that typical cement plants are very capital and labour intensive. Additionally, the cement industry has a very high frequency of shutdowns (at least four per year), thereby offering immense shutdown management knowledge base, especially owing to the fact that such shutdowns are usually executed within very short periods, making experience management very crucial.

\section{Results}

3.1. Application of Fault Tree Analysis (FTA) and Reliability Block Diagram (RBD) for Assessment of Barriers to Knowledge Management and Experience Transfer

According to [20], the success of FTAs is usually a function of the level of familiarity with the topic possessed by the investigation team and good practice requires integration of a brainstorming elements to its design. Apart from knowledge gained in this discipline, enhanced through review of relevant literatures, as well as data analysis obtained from the initiated semi-structured interviews, group decision-making was also an integral element to the entire process and was determined by setting up focus group sessions that comprised of experts from the organisation. The strict selection criteria for participant's required significant involvement in prior MoOSTs so as to ensure familiarity with identifying the main classes of probable causes that could act as barriers to MoOSTs knowledge and experience transfer, necessary for development of relevant FTAs, as well as RBDs design.

3.1.1. Global Fault Tree Analysis for Assessment of Barriers to Knowledge Management and Experience Transfer in MoOSTs

The application of FTA demonstrated in this study identified the top event as 'perceived barriers to knowledge management and experience transfer in MoOSTs management.' The contributions used in designing the FTA were based on theoretical findings, analysis of responses from semi structured interviews, and harmonisation of focus group decisions obtained from the case study (a cement manufacturing company) with appreciable frequency of performing MoOSTs. The three main classes of probable causes that could act as barriers to MoOSTs knowledge management and experience transfer are: Individual barriers (I), organisational barriers $(\mathrm{O})$, and technological barriers $(\mathrm{T})$. Figure 2 shows the global FTA for the three main classes of probable causes. 


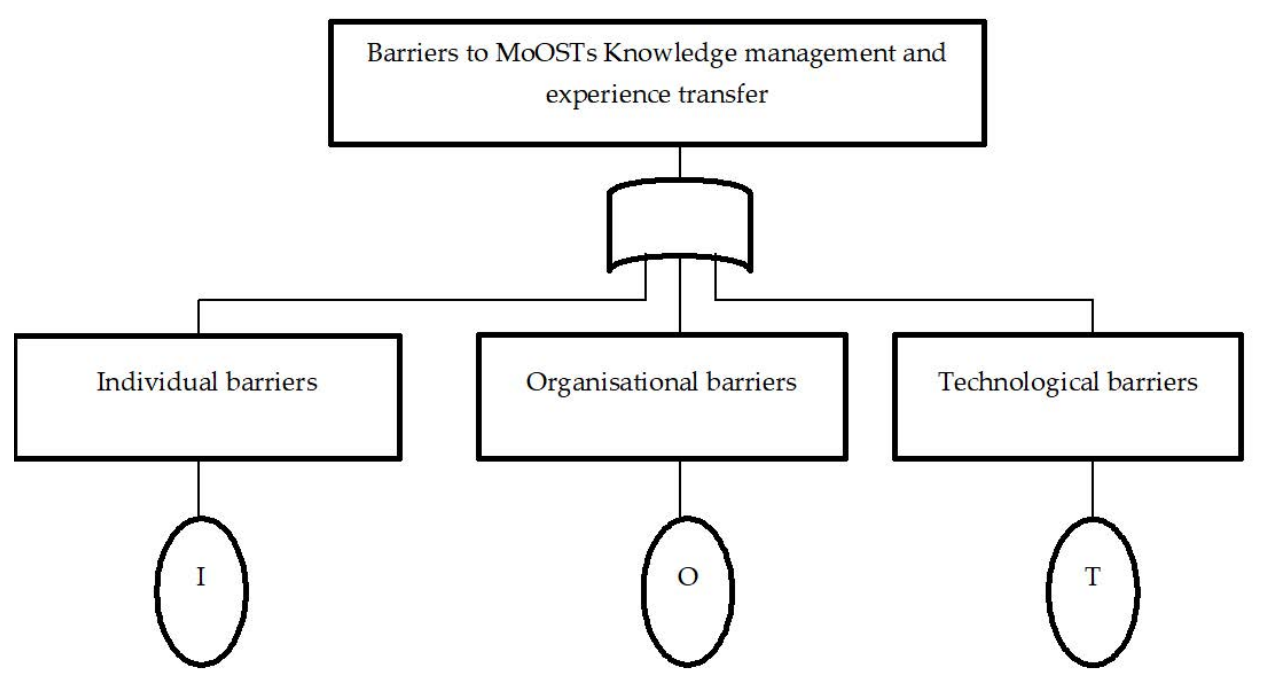

Figure 2. Global fault tree analysis for main classes of probable causes.

\subsubsection{Independent FTA for Probable Causes due to Individual Barriers}

Each of the main classes of identified probable causes making up the global FTA was developed independently, starting with the individual barriers. Detailed analysis in Figure 3 showed that two intermediate events and nine basic events contributed to the perceived barriers to knowledge management and experience transfer. Table 6 provides the assigned codes and description for each basic event.

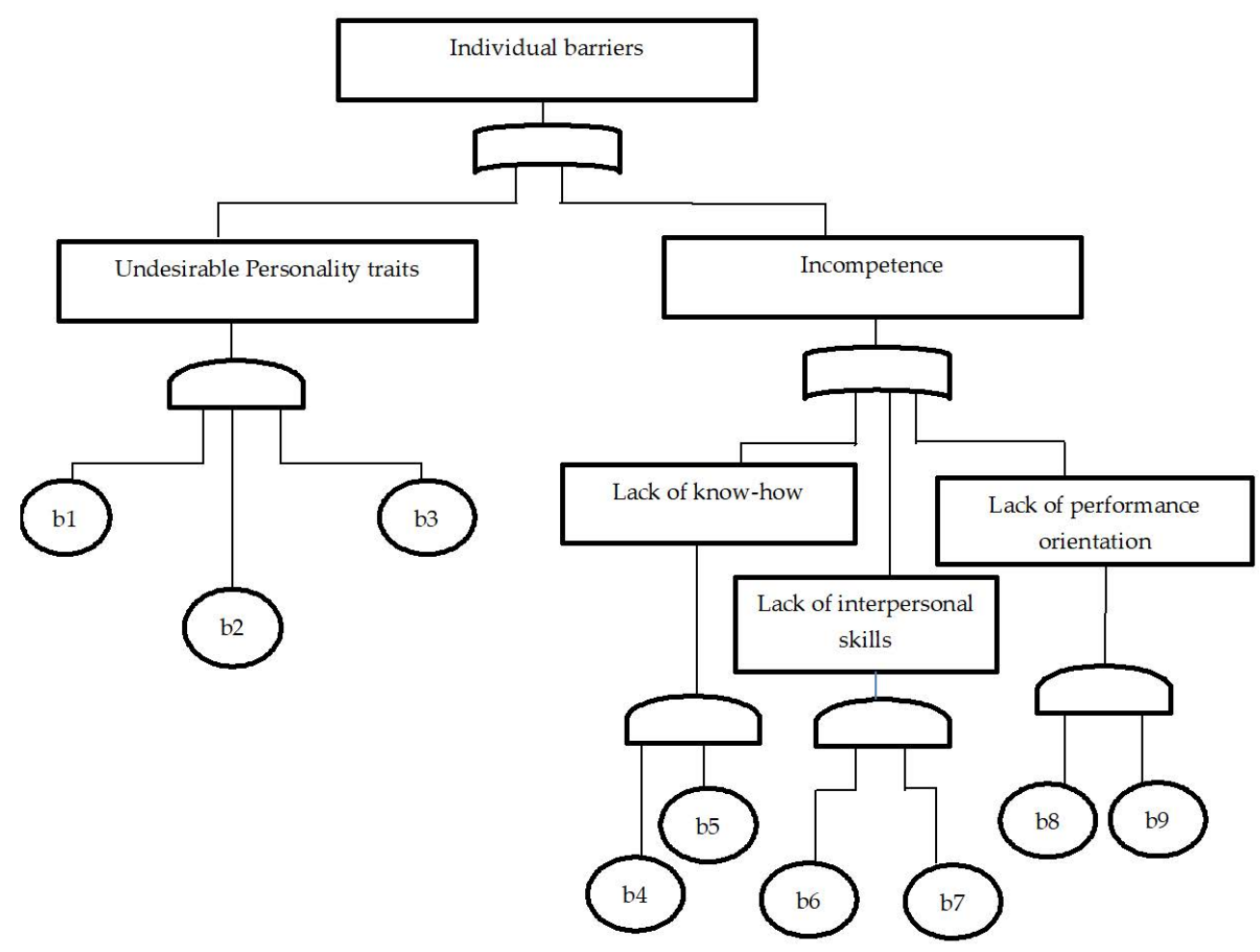

Figure 3. Independent fault tree analysis for probable causes due to individual barriers (I). 
Table 6. Assigned codes and descriptions of individual barriers' basic events.

\begin{tabular}{cc}
\hline Assigned Code & Description \\
\hline b1 & Low conscientiousness \\
b2 & Low agreeableness \\
b3 & Low openness \\
b4 & Lack of practical/technical skills \\
b5 & No awareness of strategic business orientation \\
b6 & Lack of communication skills \\
b7 & Lack of psychometric skills \\
b8 & Nonconformance to practical standards \\
b9 & Nonconformance to legal requirements \\
\hline
\end{tabular}

\subsubsection{Independent Fault Tree Analysis for Probable Causes due to Organisational Barriers}

Similarly, the FTA depicting probable causes due to organisational barriers was constructed as shown in Figure 4, which indicated that two intermediate events and eight basic events contributed to the perceived barriers to knowledge management and experience transfer. Table 7 provides the assigned codes and description for individual basic event.

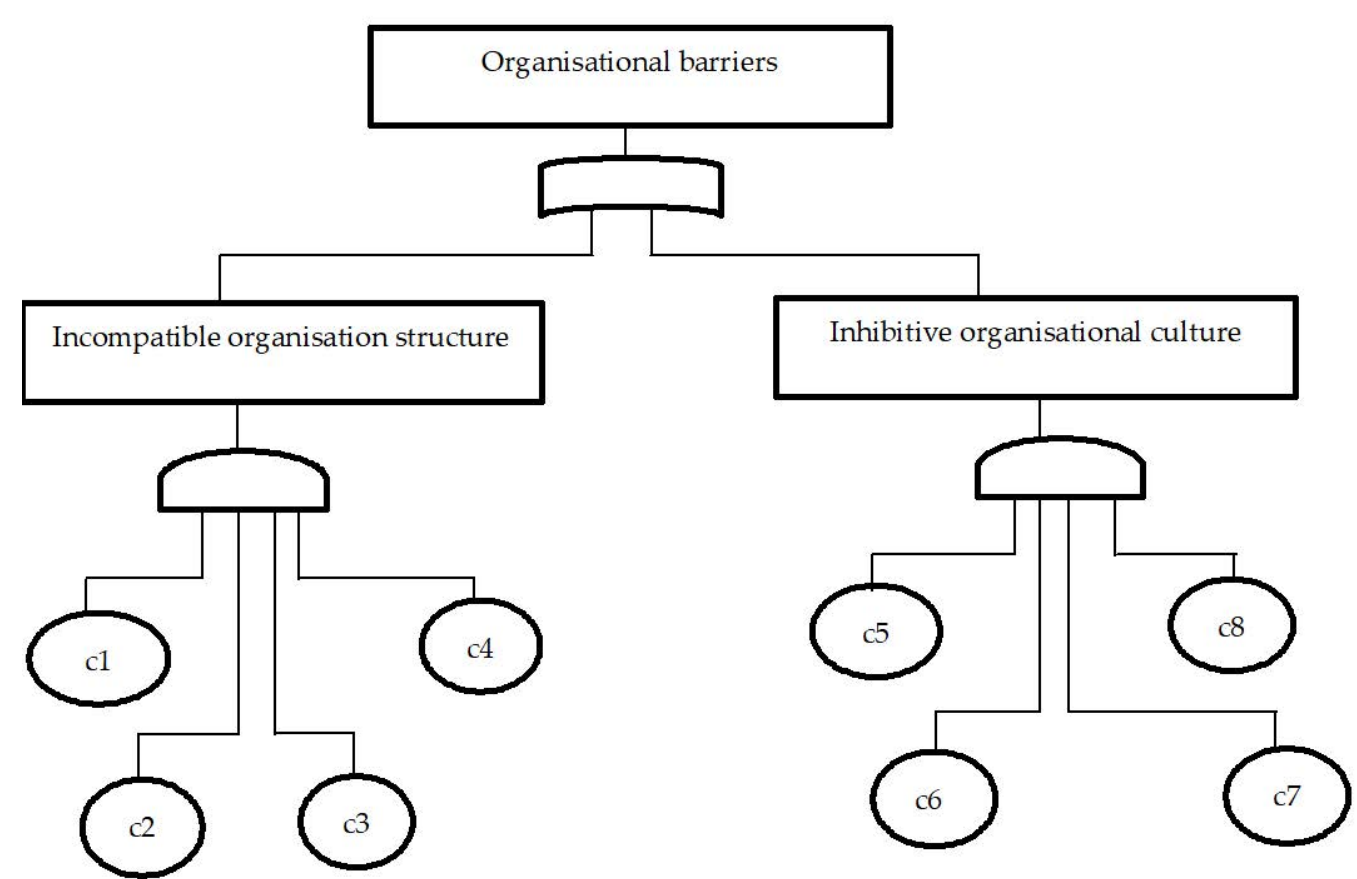

Figure 4. Independent fault tree analaysis for probable causes due to organisational barriers (O).

Table 7. Assigned codes and description for basic events under organisational barriers.

\begin{tabular}{cc}
\hline Assigned Code & Description \\
\hline c1 & Limited participation in decision making \\
c2 & Chaotic environment during MoOSTs restricts sharing \\
c3 & Limited job autonomy \\
c4 & Restricted information flow \\
c5 & Lack of leadership direction in championing values encouraging sharing \\
c6 & Lack of a reward system \\
c7 & Individualism is unduly encouraged \\
c8 & Knowledge retention of experienced staff is not prioritised \\
\hline
\end{tabular}




\subsubsection{Independent Fault Tree Analysis for Probable Causes due to Technological Barriers}

The final independent FTA concerned the generation of the causal relationships between the basic events leading to technological barriers as depicted by Figure 5. In this case, two intermediate events and six basic events were adjudged to be most influential barriers to knowledge management and experience transfer. Table 8 provides the assigned codes and descriptions for individual basic event.

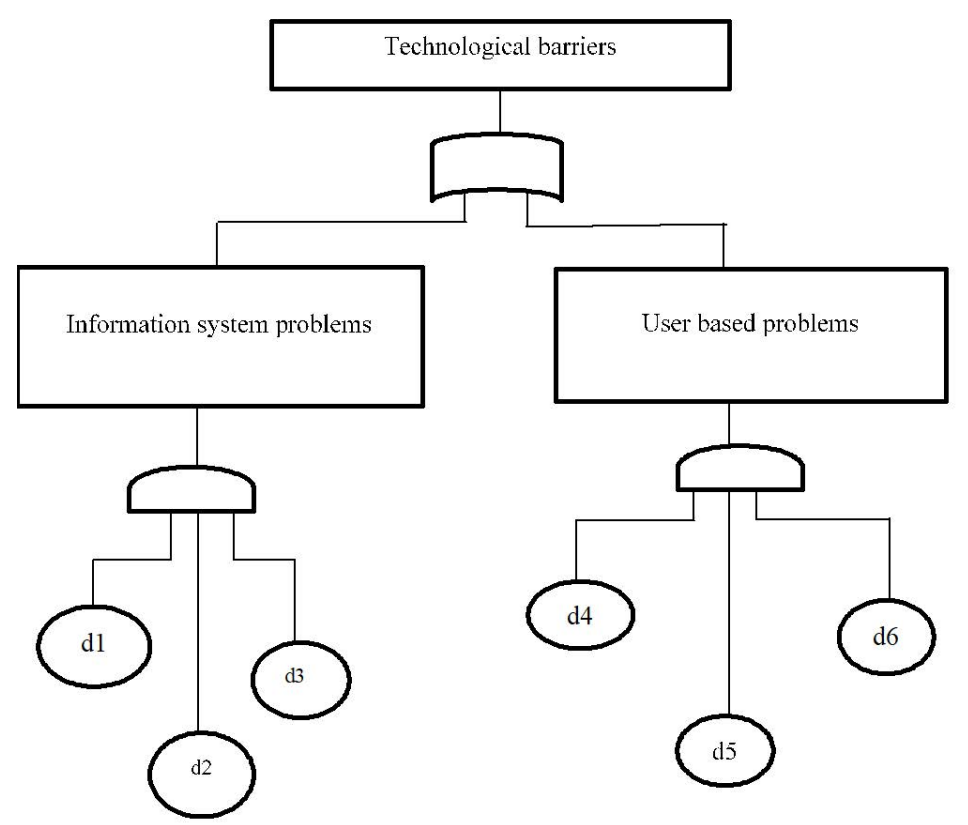

Figure 5. Independent fault tree analysis for probable causes leading to technological barriers (T).

Table 8. Assigned codes and descriptions for basic events that lead to technological barriers.

\begin{tabular}{cc}
\hline Assigned Code & Description \\
\hline $\mathrm{d} 1$ & Inability to integrate with other processes \\
$\mathrm{d} 2$ & Lack of compatibility between diverse IT systems and processes \\
$\mathrm{d} 3$ & Lack of technical support \\
$\mathrm{d} 4$ & Lack of employees interest \\
$\mathrm{d} 5$ & Lack of adequate training and development \\
$\mathrm{d} 6$ & Unrealistic expectations of capabilities of IT systems by users \\
\hline
\end{tabular}

\subsubsection{Equivalent Reliability Block Diagrams (RBDs)}

For each of the independent FTAs [21] shown in Figures 3-5, equivalent RBDs were constructed to aid visualisation. These are displayed in Figures 6-8. The usefulness of RBDs is its ability to visualise the interface of failure causes through series and parallel connections. Having developed individual equivalent RBDs (Figures 6-8), the global RBD in Figure 9 then integrates all equivalent RBDs so as to provide a holistic approach to visualisation. The main benefit of the application of RBDs in this case is dual. Firstly, it allows for easy identification of points of resilience and vulnerability as such observations may prove difficult from the FTAs alone (especially when dealing with highly dynamic problems that involve human interactions). Secondly, it can also serve as a quantitative tool if historical failure probabilities are available. In this case, decision-makers can easily estimate overall system vulnerability, as well as predict failure possibilities in advance, so that adequate corrective measures can be initiated. Within all of the constructed RBDs (i.e., equivalent (Figures 6-8) and global (Figure 9)), there exists several series relationships between individual intermediate events, as well as their associated basic events, thereby indicating high system vulnerabilities and multiple failure causes. 


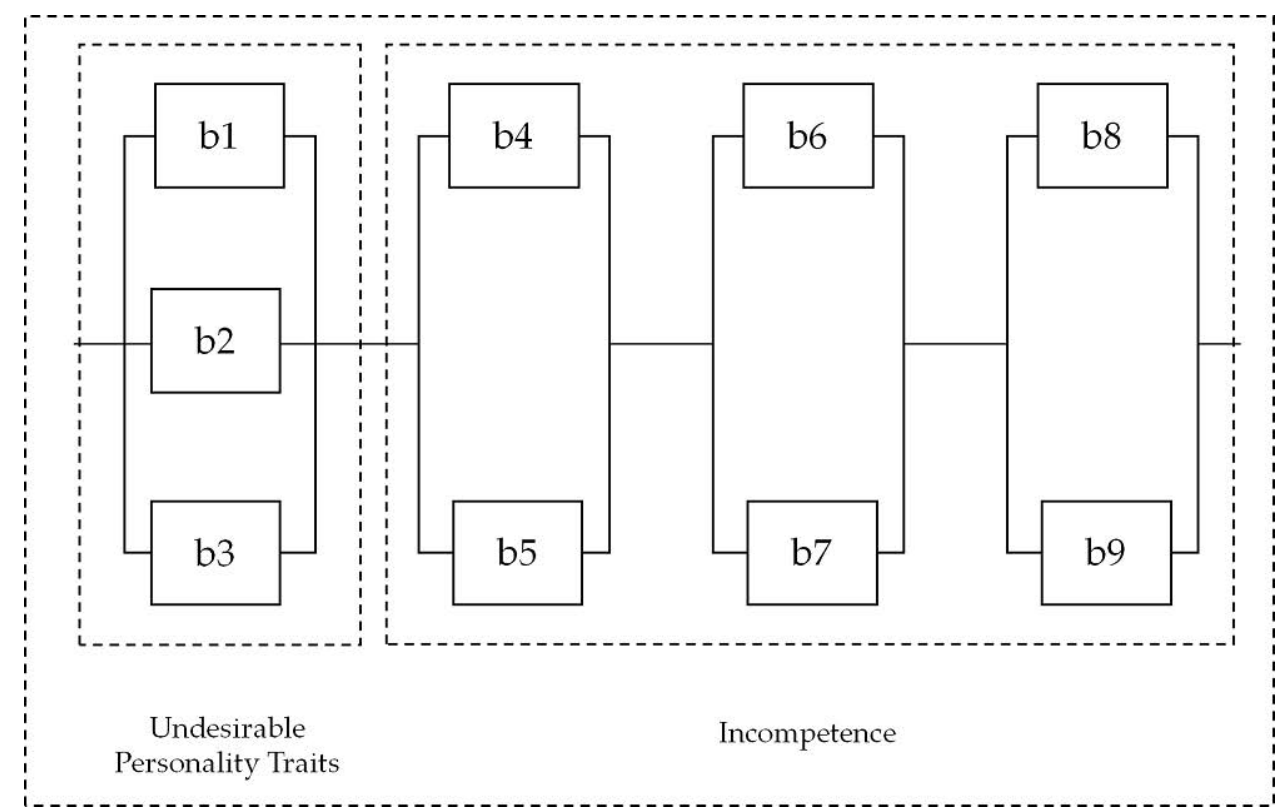

Figure 6. Equivalent reliability block diagram for probable causes due to individual barriers (I).

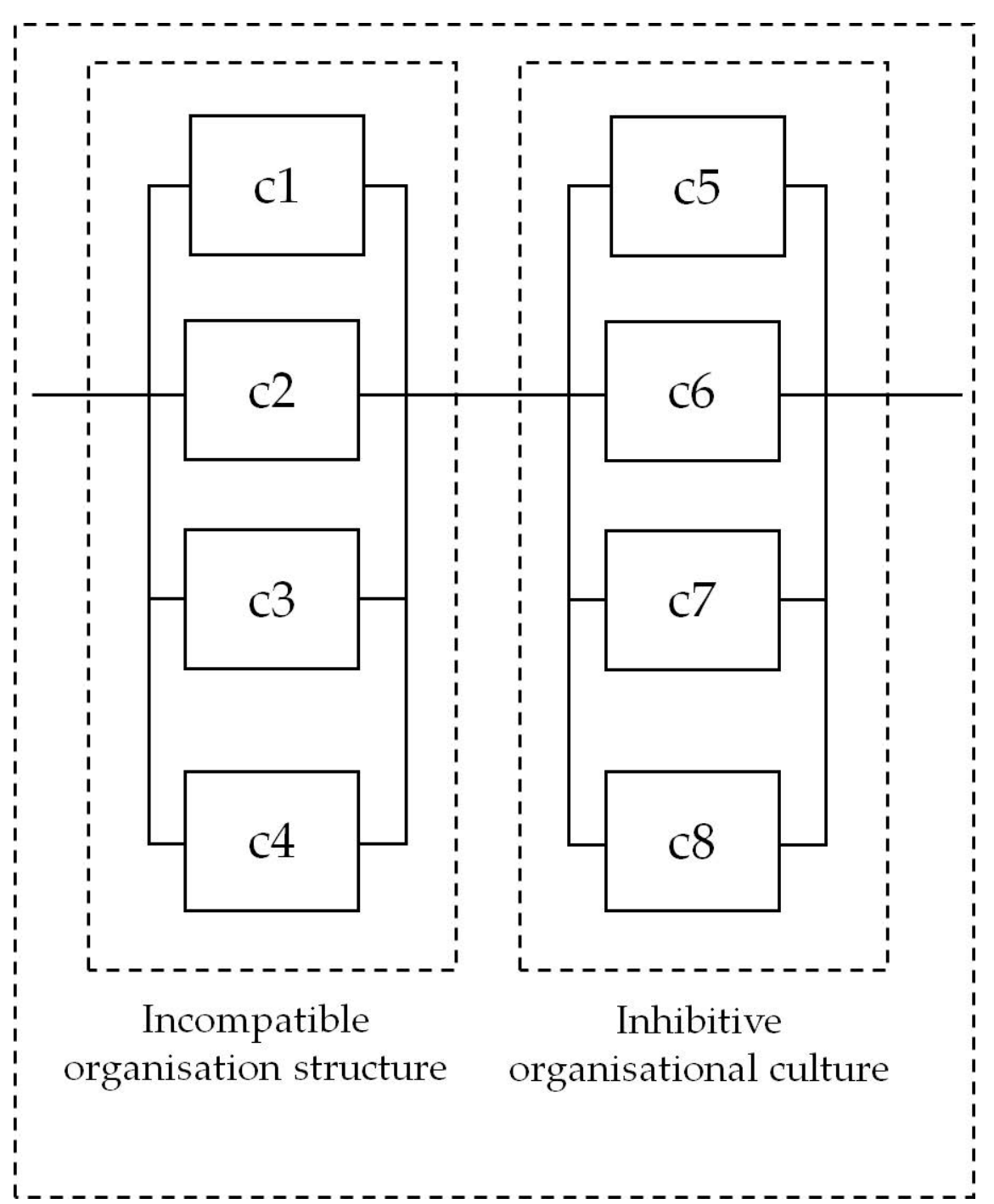

Figure 7. Equivalent reliability block diagram for probable causes due to organisational barriers $(\mathrm{O})$. 


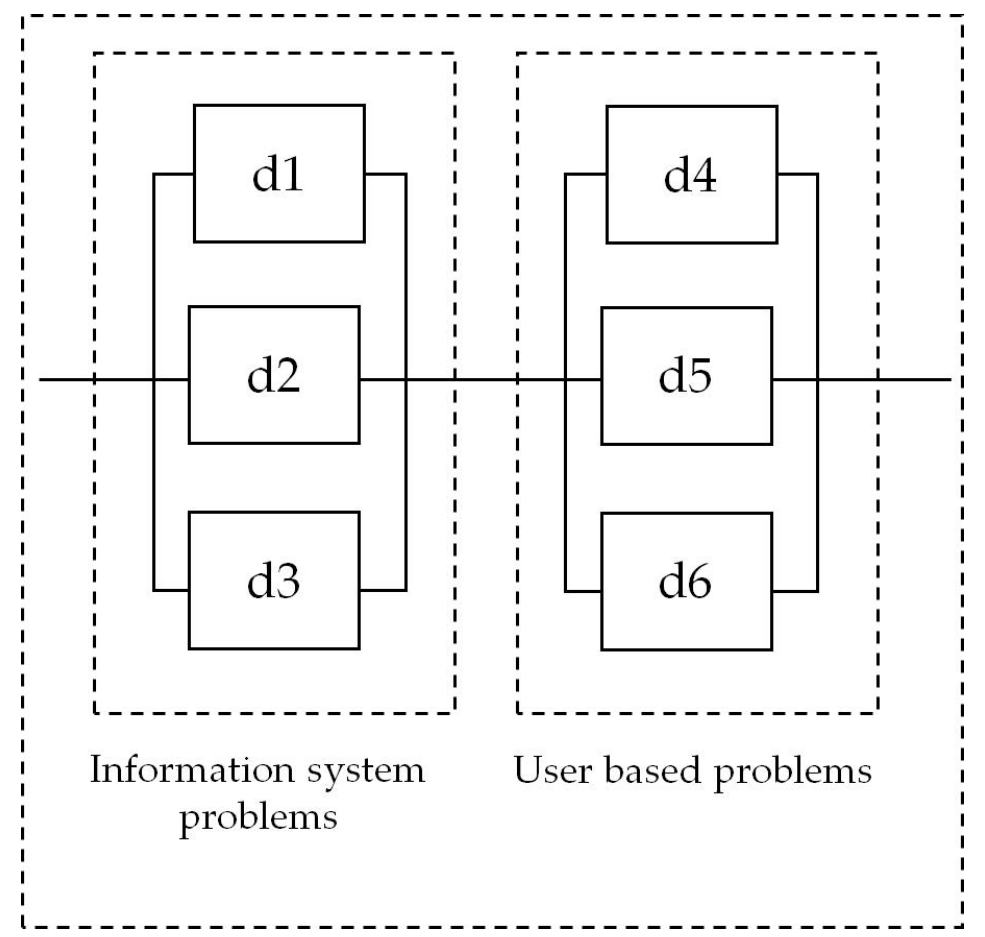

Figure 8. Equivalent reliability block diagram for probable causes due to technological barriers (T).

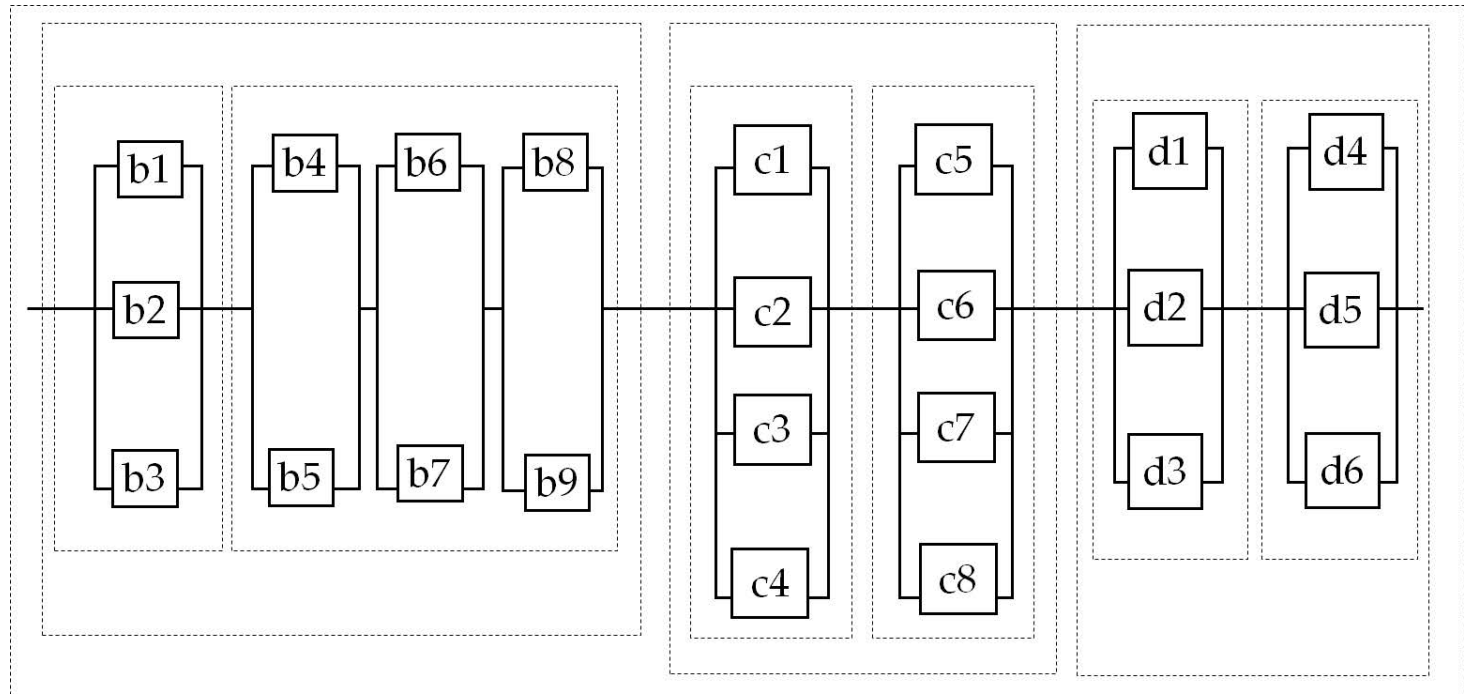

Figure 9. Global reliability block diagram integrating equivalent reliability block diagrams of each resultant fault tree analysis.

3.2. Application of Analytical Heirarchy Process for Assessment of Barriers to Knowledge Management and Experience Transfer

The application of AHP in this section involves group decision-making, so as to elicit responses used to generate pairwise comparisons. The hierarchy of problems was developed as shown in Figure 10. Thereafter, decision makers in the group indicated their preferences and priorities for each of the main probable causes of failures, as well as ranking of basic failure events that trigger them. The results shown in Appendix B (Tables A5-A8), respectively represent the outcomes of manual and automated (based on Transparent Choice AHP software) pairwise comparisons and syntheses based on the descriptions provided in $[35,36]$. The aim was to rank the three main criteria (i.e., intermediate event identified from FTA in Figure 2) and 23 subcriteria (basic events identified from FTAs in Figures 3-5). The description of hierarchy elements can be found in Appendix C (Table A9). 


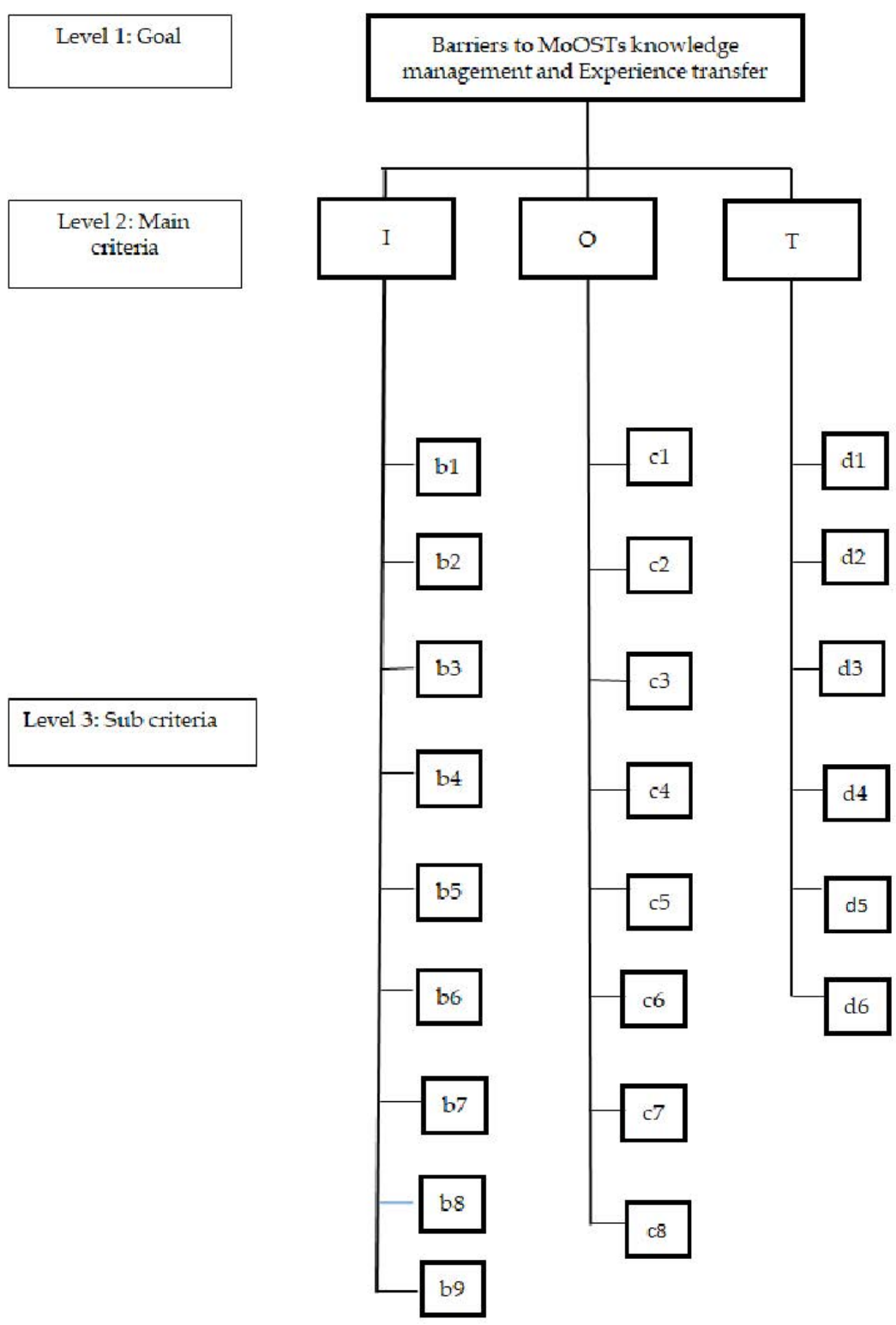

Figure 10. Problem hierarchy.

The syntheses of pairwise comparisons are performed by division of each element of the matrix by its column total. In Table A5 for instance, to obtain the synthesised pairwise comparison matrix for the three main criteria, the value of each cell after pairwise comparison is a function of the ratio of sum of each column to the value of the cell (i.e., $1+3+1 / 5$ which equals 4.2 ; subsequently cell 1.1 divided by 4.2 equals 0.24 ; hence the value shown in the first cell of the synthesised matrix ' $\mathrm{I}$ '). The priority matrix for Table A5 was obtained by estimating the ratio of the row averages (i.e., sum total of rows ' $\mathrm{I}$ ', ' $\mathrm{O}$ ', and 'T) to sum of the column. Similar steps were then replicated to obtain the synthesised matrix and local priorities for the subcriteria associated with each main criterion in Tables A6-A8 (Appendix B). CR values for Tables A5-A8 (Appendix B) is less than 0.1, indicating that judgements are within acceptable limits. Correspondingly, Transparent Choice software can automatically perform the calculations, provided correct values for the pairwise comparisons are allocated. Appendix A (Tables A1-A4) shows that the results obtained from the analysis done using Transparent Choice is quite similar. The overall priorities depicted in Table 9 were obtained through products of the sub and main criteria. 
Table 9. Overall priorities ranking of barriers to knowledge management and experience transfer.

\begin{tabular}{|c|c|c|c|c|}
\hline Criteria & Assigned Code & Subcriteria Local Weight & Global Weight & Ranking \\
\hline \multirow{10}{*}{ Individual Barriers } & I & 0.28 & - & - \\
\hline & b1 & 0.028 & 0.008 & 19 \\
\hline & $\mathrm{b} 2$ & 0.028 & 0.008 & 19 \\
\hline & b3 & 0.028 & 0.008 & 19 \\
\hline & b4 & 0.259 & 0.073 & 5 \\
\hline & b5 & 0.259 & 0.073 & 5 \\
\hline & b6 & 0.062 & 0.017 & 13 \\
\hline & b7 & 0.062 & 0.017 & 13 \\
\hline & b8 & 0.156 & 0.044 & 8 \\
\hline & b9 & 0.119 & 0.033 & 10 \\
\hline \multirow{9}{*}{ Organisational Barriers } & $\mathrm{O}$ & 0.64 & - & - \\
\hline & c1 & 0.028 & 0.018 & 12 \\
\hline & c2 & 0.030 & 0.019 & 10 \\
\hline & c3 & 0.025 & 0.016 & 15 \\
\hline & $c 4$ & 0.286 & 0.183 & 1 \\
\hline & c5 & 0.092 & 0.059 & 7 \\
\hline & c6 & 0.134 & 0.086 & 4 \\
\hline & c7 & 0.146 & 0.093 & 3 \\
\hline & c8 & 0.258 & 0.165 & 2 \\
\hline \multirow{7}{*}{ Technological Barriers } & $\mathbf{T}$ & 0.08 & - & - \\
\hline & $\mathrm{d} 1$ & 0.157 & 0.013 & 16 \\
\hline & $\mathrm{d} 2$ & 0.167 & 0.013 & 16 \\
\hline & $\mathrm{d} 3$ & 0.117 & 0.009 & 18 \\
\hline & $\mathrm{d} 4$ & 0.068 & 0.005 & 22 \\
\hline & $\mathrm{d} 5$ & 0.448 & 0.036 & 9 \\
\hline & d6 & 0.041 & 0.003 & 23 \\
\hline
\end{tabular}

\section{Discussion}

MoOSTs knowledge management (including acquisition, transfer, and learning) is particularly challenging due to variabilities in the frequency of the events, leading to limited growth in individual and organisational learning. Despite the enormous benefits of knowledge management to organisational growth and succession planning, organisational learning difficulties still persists in a wide range of disciplines, including MoOSTs [10]. The novel reliability-based analysis conducted here identified the main limiters in the context of individual, organisation, and technology, using FTAs and RBDs. The harmonisation of FTA and RBD as visualisation techniques resulted in the identification of 23 basic events as shown in Figures 3-5. The global FTA in Figure 10 highlighted significant bias towards system vulnerability (i.e., series relationships) despite the observed parallel relationships observable among the basic events of individual equivalent RBDs (i.e., Figures 6-8).

In general, there were nine, eight, and six subcriteria related to individual, organisational, and technological barriers as shown in Figure 7. The most highly ranked subcriteria were all associated with organisational barriers especially c4, c6, c7, and c8 (Table 7). The next highly ranked subcriteria were related to individual barriers which were most influenced by b4 and b5 (Table 6). Technological barriers were the least ranked, with lack of adequate training (d5) on newly deployed technologies being the most influential (Table 8). The dominance of organisational barriers adequately aligns with the findings of earlier studies $[3,10,13]$ that clearly advocate the need to revisit existing practices to knowledge management within organisations. Further dissection of the intermediate events associated with organisational barriers revealed that incompatible organisation structures and inhibitive organisation culture as the main root causes.

Typical MoOSTs environments is characterised by interfaces between staff, contractors, and subcontractors within the client's site, which often impedes voluntary knowledge and experience dissemination. Responses gathered from the field-based focus group session attributed this tendency to 
hoard knowledge (especially by contractors and subcontractors) to fears of losing relevance once such expert knowledge is released. Additionally, it is very common for MoOSTs to operate under strict time restrictions, which sometimes restricts decision-making to the top echelon of management staff, thereby inhibiting job autonomy. In the case of barriers attributed to inhibitive culture, the findings from the case has identified issues related to nonprioritisation of knowledge retention within experienced staff, unduly encouraging individualism, and a lack of reward systems. Hence, misallocation and/or misalignment of human resources and process has resulted in the emergence of organisations that lack capacity in harnessing the immense resources at their disposal.

A cursory examination of Figure 3 indicated that undesirable personality traits and incompetence dominated individual barriers. Drilling down into the personality traits element exposed three common factors, namely: Agreeableness, conscientiousness, and openness. All three common factors recorded similar scores which buttresses the importance of combining these traits in order to obtain desired results. In addition, [43-46] have claimed that personality traits have huge impacts on how individuals share work related knowledge, expertise, and contributions within an organisation. Moreover, competence is indicated by having the necessary practical/technical skills along with a high awareness of strategic business orientation. However, deficiencies in any of the elements could independently lead to the undesired top-level event because only experienced staff can effectively transfer residual (tacit) knowledge. That is, if an experienced staff (defined by their virtue of long term involvement in MoOSTs) is deficient in any combination of limited interpersonal skills, (including communication skills-verbal or written), as well as having undesirable personality traits that restricts people from seeking them out for the skills they possess, (i.e., ranked low on openness, agreeableness, and contentiousness), then potential barriers for knowledge sharing increases. Consequently, if all of these desired factors are missing, less experienced or inexperienced staff would be unable to benefit, which raises the likelihood of tacit knowledge flow, which consequently results to over-reliance on explicit knowledge.

Technology also has a critical role in establishing performance of knowledge management systems, especially with respect to staff training, and integration with established processes [3,47-50]. While responses from identification and ranking of main criteria and subcriteria related to this element were lowly ranked in comparison to other main criteria and subcriteria, however, the interactions between people and technology facilitates retention and sharing of knowledge. The two main issues highlighted were information systems problems and user-based problems. On the one hand, the top ranked subcriterion was lack of adequate training related with the use of information systems (d5). On the other hand, inability to integrate new systems with existing legacy systems (d1) and lack of compatibility between diverse IT systems/processes (d2) were equally ranked. It is envisaged that developing the competence of users would lead to self-managed teams and facilitate acquisition and transfer of tacit knowledge.

Finally, findings from each of the techniques implemented in this study have brought to focus the usefulness of using a hybrid of techniques for problem identification, which can either generate quantitative solutions where historical failure probabilities are available or to simply generate qualitative visualisation platforms that can support conventional root causes analyses. FTAs were useful in designing the hierarchy of problems, clearly highlighting causal factors. RBDs on the other hand showed the combination of series and parallel connections within the systems, indicating fragility in combinatorial relationship, owing primarily to many series systems setups. The use of AHP to rank and prioritise the hierarchy of problems is perhaps one of the most vital pieces of the whole results because scarcity of resources informs decision-making and facilitates selection of choices. Through ranking of main criteria and subcriteria, decision makers can design viable solutions starting with the top ranked criteria and then work their way to the bottom ranked criteria. The implementation of choices can be done in phases and decision makers can attempt to map-out long-term/short-term objectives, based on information obtained from ranking of criteria. 


\section{Conclusions}

It is well acknowledged that there exists several mechanisms with the MoOSTs community of most organisations for capturing knowledge, including post-mortem meetings, pre/post-shutdown debriefing meetings, etc. As valuable as these mechanisms have proven to be over the decades, they are mainly geared towards capturing and disseminating explicit knowledge. This is perhaps owing to the ease of capturing and measuring such classes of knowledge within organisations. While this may be effective for mundane activities, the time, cost, and quality constraints associated with core MoOSTs activities make it imperative to possess substantial tacit knowledge. Through the combination of information existing within current body of knowledge, as well as a practical case study, the present study investigated the casual relationships that exist among the main barriers to MoOSTs knowledge management and experience transfer. The study also takes into cognisance, the inability of decision-makers to confront all issues within their organisation due to budget restrictions thereby necessitating the creation of mechanisms that allow for the prioritisation of the most influential factors. The most important contribution of this work includes intuitively harmonising several reliability-based (FTA and RBD) and multiple criteria decision-making (AHP) tools. This presents a practical but yet realistic model for understanding limiters to intangible performance enhancement elements of a very crucial industrial activity, MoOSTs. Furthermore, priority ranking derived from AHP provides a road map that can direct focus of decision makers accordingly, especially when providing alternatives/solutions. This implies that holistic alternatives based on identified MoOSTs barriers to knowledge management and experience transfer can be derived and ranked appropriately. While the individual tools applied here are well-established within research and professional communities, their integration and application for solving MoOSTs knowledge management issues has never been explored. Moreover, the use of tools that are relatively familiar to the professional community is viewed as means of reducing the steepness of the learning curve that sometimes plagues the deployment of theoretical tools to the industry.

The scope of this work was limited to developing a hierarchy of problems capable of ranking and identifying the order of barriers to MoOSTs knowledge management and experience transfer, and as such has not attempted to provide solutions in terms of alternatives. While the novel harmonisation of theoretical quantitative risk assessment tools with qualitative field-based perspectives from experts can significantly enhance the ability of decision-makers to identify deficiencies in knowledge transfer mechanisms at a glance, the findings presented here can be described as being industry-specific. Despite this perceived limitation, it is envisaged that the approach presented here still offers useful contributions especially that cement manufacturing is often considered the upstream segment of one of the largest business sectors (i.e., mining and construction). Future works are planned to encompass other key sectors (e.g., oil and gas, energy, food and beverage, etc.), as well as consider appropriate alternatives that consider the whole facet of MoOSTs in terms of tasks and associated knowledge, for the purpose of developing a knowledge management and experience transfer model specific to MoOSTs, which constitutes an essential step towards systematic but yet sustainable framework for tacit knowledge retention.

Author Contributions: Conceptualization, L.O.I.-E. and A.Y.K.; methodology, L.O.I.-E. and A.Y.K.; validation, L.O.I.-E. and A.Y.K.; formal data analysis, L.O.I.-E.; investigation, L.O.I.-E. and A.Y.K.; writing-original draft preparation, L.O.I.-E.; writing-review and editing, A.Y.K.; supervision, A.Y.K. All authors have read and agreed to the published version of the manuscript.

Funding: No external funding was received to support this work.

Conflicts of Interest: The authors declare no conflict of interest.

\section{Appendix A}

Synthesized pairwise comparison results using AHP software 'Transparent Choice'. 
Table A1. Criteria weights by aggregate of all evaluators for main classes of probable causes.

\begin{tabular}{cccc}
\hline \multirow{2}{*}{ S/No. } & Criterion & \multicolumn{2}{c}{ Weight } \\
\cline { 3 - 4 } & & Local & Global \\
\hline 1 & Individual barriers & 0.28 & 0.28 \\
2 & Organisation barriers & 0.65 & 0.65 \\
3 & Technology barriers & 0.07 & 0.07 \\
\hline
\end{tabular}

Table A2. Criteria weights by aggregate of all evaluators for individual barriers.

\begin{tabular}{cccc}
\hline \multirow{2}{*}{ S/No. } & Criterion & \multicolumn{2}{c}{ Weight } \\
\cline { 3 - 4 } & & Local & Global \\
\hline 1 & b1 & 0.03 & 0.03 \\
2 & b2 & 0.03 & 0.03 \\
3 & b3 & 0.03 & 0.03 \\
4 & b4 & 0.26 & 0.26 \\
5 & b5 & 0.26 & 0.26 \\
6 & b6 & 0.06 & 0.06 \\
7 & b7 & 0.06 & 0.06 \\
8 & b8 & 0.16 & 0.16 \\
9 & b9 & 0.11 & 0.11 \\
\hline
\end{tabular}

Table A3. Criteria weights by aggregate of all evaluators for organization barriers.

\begin{tabular}{cccc}
\hline \multirow{2}{*}{ S/No. } & Criterion & \multicolumn{2}{c}{ Weight } \\
\cline { 3 - 4 } & & Local & Global \\
\hline 1 & c1 & 0.03 & 0.03 \\
2 & c2 & 0.03 & 0.03 \\
3 & c3 & 0.02 & 0.02 \\
4 & c4 & 0.32 & 0.32 \\
5 & c5 & 0.08 & 0.08 \\
6 & c6 & 0.13 & 0.13 \\
7 & c7 & 0.13 & 0.13 \\
8 & c8 & 0.26 & 0.26 \\
\hline
\end{tabular}

Table A4. Criteria weights by aggregate of all evaluators for technological barriers.

\begin{tabular}{cccc}
\hline \multirow{2}{*}{ S/No. } & Criterion & \multicolumn{2}{c}{ Weight } \\
\cline { 3 - 4 } & & Local & Global \\
\hline 1 & $\mathrm{~d} 1$ & 0.15 & 0.15 \\
2 & $\mathrm{~d} 2$ & 0.17 & 0.17 \\
3 & $\mathrm{~d} 3$ & 0.11 & 0.11 \\
4 & $\mathrm{~d} 4$ & 0.07 & 0.07 \\
5 & $\mathrm{~d} 5$ & 0.46 & 0.46 \\
6 & $\mathrm{~d} 6$ & 0.04 & 0.04 \\
\hline
\end{tabular}




\section{Appendix B}

Table A5. Synthesised matrix of the three main classes of probable causes.

\begin{tabular}{cccccc}
\hline & $\mathbf{I}$ & $\mathbf{O}$ & $\mathbf{T}$ & Priority Vector & Transparent Choice \\
\hline $\mathbf{I}$ & 0.24 & 0.23 & 0.38 & 0.28 & 0.28 \\
$\mathbf{O}$ & 0.71 & 0.68 & 0.54 & 0.64 & 0.65 \\
$\mathbf{T}$ & 0.048 & 0.10 & 0.08 & 0.08 & 0.07 \\
\hline- & - & - & - & $\sum=1$ & - \\
\hline
\end{tabular}

Note: $\lambda_{\max }=3.065, \mathrm{CI}=0.0325, \mathrm{RI}=0.58, \mathrm{CR}=0.06<0.1 \mathrm{OK}$.

Table A6. Synthesised matrix for subcriteria associated with individual barriers.

\begin{tabular}{cccccccccccc}
\hline $\mathbf{I}$ & $\mathbf{b} \mathbf{1}$ & $\mathbf{b} 2$ & $\mathbf{b 3}$ & $\mathbf{b} 4$ & $\mathbf{b 5}$ & $\mathbf{b 6}$ & $\mathbf{b} 7$ & $\mathbf{b 8}$ & $\mathbf{b 9}$ & $\begin{array}{c}\text { Priority } \\
\text { Vector }\end{array}$ & $\begin{array}{c}\text { Transparent } \\
\text { Choice }\end{array}$ \\
\hline $\mathbf{b 1}$ & 0.030 & 0.030 & 0.030 & 0.041 & 0.041 & 0.018 & 0.018 & 0.023 & 0.016 & 0.028 & 0.03 \\
$\mathbf{b 2}$ & 0.030 & 0.030 & 0.030 & 0.041 & 0.041 & 0.018 & 0.018 & 0.023 & 0.016 & 0.028 & 0.03 \\
$\mathbf{b 3}$ & 0.030 & 0.030 & 0.030 & 0.041 & 0.041 & 0.018 & 0.018 & 0.023 & 0.016 & 0.028 & 0.03 \\
$\mathbf{b 4}$ & 0.212 & 0.212 & 0.212 & 0.286 & 0.286 & 0.263 & 0.263 & 0.352 & 0.245 & 0.259 & 0.26 \\
$\mathbf{b 5}$ & 0.212 & 0.212 & 0.212 & 0.286 & 0.286 & 0.263 & 0.263 & 0.352 & 0.245 & 0.259 & 0.26 \\
$\mathbf{b 6}$ & 0.091 & 0.091 & 0.091 & 0.057 & 0.057 & 0.053 & 0.053 & 0.039 & 0.027 & 0.062 & 0.06 \\
$\mathbf{b 7}$ & 0.091 & 0.091 & 0.091 & 0.057 & 0.057 & 0.053 & 0.053 & 0.039 & 0.027 & 0.062 & 0.06 \\
$\mathbf{b 8}$ & 0.152 & 0.152 & 0.152 & 0.095 & 0.095 & 0.158 & 0.158 & 0.117 & 0.326 & 0.156 & 0.16 \\
b9 & 0.152 & 0.152 & 0.152 & 0.095 & 0.095 & 0.158 & 0.158 & 0.029 & 0.082 & 0.119 & 0.11 \\
\hline- & - & - & - & - & - & - & - & - & - & $\sum=1$ & - \\
\hline
\end{tabular}

Note: $\lambda_{\max }=9.447, \mathrm{CI}=0.0559, \mathrm{RI}=1.45, \mathrm{CR}=0.039<0.1 \mathrm{OK}$.

Table A7. Synthesised matrix for subcriteria associated with organisational barriers.

\begin{tabular}{ccccccccccc}
\hline O & $\mathbf{c 1}$ & $\mathbf{c 2}$ & $\mathbf{c 3}$ & $\mathbf{c 4}$ & $\mathbf{c 5}$ & $\mathbf{c 6}$ & $\mathbf{C 7}$ & $\mathbf{C} 8$ & $\begin{array}{c}\text { Priority } \\
\text { Vector }\end{array}$ & $\begin{array}{c}\text { Transparent } \\
\text { Choice }\end{array}$ \\
\hline $\mathbf{c 1}$ & 0.030 & 0.037 & 0.024 & 0.059 & 0.014 & 0.019 & 0.020 & 0.021 & 0.028 & 0.03 \\
c2 & 0.030 & 0.037 & 0.024 & 0.074 & 0.023 & 0.019 & 0.015 & 0.021 & 0.030 & 0.03 \\
c3 & 0.030 & 0.037 & 0.024 & 0.053 & 0.010 & 0.014 & 0.011 & 0.021 & 0.025 & 0.02 \\
c4 & 0.182 & 0.007 & 0.167 & 0.370 & 0.204 & 0.474 & 0.307 & 0.577 & 0.286 & 0.32 \\
c5 & 0.152 & 0.110 & 0.167 & 0.123 & 0.068 & 0.047 & 0.034 & 0.038 & 0.092 & 0.08 \\
c6 & 0.152 & 0.184 & 0.167 & 0.074 & 0.136 & 0.095 & 0.204 & 0.064 & 0.134 & 0.13 \\
c7 & 0.152 & 0.257 & 0.214 & 0.123 & 0.204 & 0.047 & 0.102 & 0.064 & 0.146 & 0.13 \\
c8 & 0.273 & 0.331 & 0.214 & 0.123 & 0.341 & 0.285 & 0.307 & 0.192 & 0.258 & 0.26 \\
\hline- & - & - & - & - & - & - & - & - & $\sum=1$ & - \\
\hline \multicolumn{7}{c}{ Note: $\lambda_{\max }=8.688, \mathrm{CI}=0.09828, \mathrm{RI}=1.41, \mathrm{CR}=0.07<0.1 \mathrm{OK}}$. &
\end{tabular}

Table A8. Synthesised matrix for subcriteria associated with technological barriers.

\begin{tabular}{ccccccccc}
\hline $\mathbf{T}$ & $\mathbf{d} 1$ & $\mathbf{d} 2$ & $\mathbf{d} 3$ & $\mathbf{d} 4$ & $\mathbf{d} 5$ & $\mathbf{d 6}$ & $\begin{array}{c}\text { Priority } \\
\text { Vector }\end{array}$ & $\begin{array}{c}\text { Transparent } \\
\text { Choice }\end{array}$ \\
\hline $\mathbf{d 1}$ & 0.153 & 0.124 & 0.094 & 0.184 & 0.161 & 0.227 & 0.157 & 0.15 \\
$\mathbf{d} 2$ & 0.153 & 0.124 & 0.281 & 0.122 & 0.096 & 0.227 & 0.167 & 0.17 \\
$\mathbf{d} 3$ & 0.153 & 0.041 & 0.094 & 0.184 & 0.096 & 0.136 & 0.117 & 0.11 \\
$\mathbf{d 4}$ & 0.051 & 0.062 & 0.031 & 0.061 & 0.069 & 0.136 & 0.068 & 0.07 \\
$\mathbf{d 5}$ & 0.459 & 0.622 & 0.469 & 0.429 & 0.482 & 0.227 & 0.448 & 0.46 \\
$\mathbf{d 6}$ & 0.031 & 0.025 & 0.031 & 0.020 & 0.096 & 0.045 & 0.041 & 0.04 \\
\hline- & - & - & - & - & - & - & $\sum=1$ & - \\
\hline
\end{tabular}

Note: $\lambda_{\max }=6.451, \mathrm{CI}=0.09015, \mathrm{RI}=1.24, \mathrm{CR}=0.073<0.1 \mathrm{OK}$. 


\section{Appendix C}

Table A9. Hierarchy elements and their brief descriptions.

\begin{tabular}{|c|c|c|}
\hline Assigned Code & Hierarchy Elements & Brief Description of Hierarchy Elements \\
\hline b1 & Low conscientiousness & $\begin{array}{l}\text { Employees who score low on the ability to } \\
\text { systematically codify experiences (i.e., tacit } \\
\text { knowledge) gained from each MoOSTs cycle into } \\
\text { written documents/procedures (explicit } \\
\text { knowledge) that can benefit others in the future. }\end{array}$ \\
\hline b2 & Low agreeableness & $\begin{array}{l}\text { Employees who score low on cooperative } \\
\text { interactions and willingness to work with others } \\
\text { in order to learn and share knowledge for mutual } \\
\text { benefits of the team. }\end{array}$ \\
\hline b3 & Low openness & $\begin{array}{c}\text { Employees who score low in the ability to actively } \\
\text { seek and imbibe new learning experiences from } \\
\text { social workplace teams or individuals. }\end{array}$ \\
\hline b4 & Lack of practical/technical skills & $\begin{array}{l}\text { Employees with little or no training, practical } \\
\text { involvement for performing MoOSTs, } \\
\text { and technical skills for accomplishing } \\
\text { maintenance tasks will be unable to transfer same } \\
\text { skills to others. }\end{array}$ \\
\hline b5 & $\begin{array}{l}\text { No awareness of strategic } \\
\text { business orientation }\end{array}$ & $\begin{array}{l}\text { Employees who are unaware of links between } \\
\text { their immediate responsibilities to the entire } \\
\text { business goals. }\end{array}$ \\
\hline b6 & Lack of communication skills & $\begin{array}{l}\text { Employees who lack requisite oral, written, } \\
\text { and behavioural skills necessary to encourage } \\
\text { human interactions within their workplace can } \\
\text { limit the extent of sharing. }\end{array}$ \\
\hline b7 & Lack of psychometric skills & $\begin{array}{l}\text { Employees who lack aptitude (competencies, } \\
\text { absorptive, and retentive capacity) can hamper } \\
\text { learning and sharing. }\end{array}$ \\
\hline b8 & $\begin{array}{l}\text { Nonconformance to practical } \\
\text { standards }\end{array}$ & $\begin{array}{l}\text { Employees who are not trained on performance } \\
\text { orientations based on adherence to practical } \\
\text { standards for performing MoOSTs activities can } \\
\text { limit the ability to transfer lessons learned. }\end{array}$ \\
\hline b9 & $\begin{array}{l}\text { Nonconformance to legal } \\
\text { requirements }\end{array}$ & $\begin{array}{l}\text { Employees who are not trained on performance } \\
\text { orientations based on adherence to legal } \\
\text { standards for performing MoOSTs activities can } \\
\text { limit the ability to transfer lessons learned. }\end{array}$ \\
\hline $\mathrm{c} 1$ & $\begin{array}{l}\text { Limited participation in } \\
\text { decision-making }\end{array}$ & $\begin{array}{l}\text { Organisations where decisions are taken } \\
\text { unilaterally in isolation, without seeking inputs } \\
\text { from people involved in different facets of } \\
\text { MoOSTs limit the extent of learning and sharing. }\end{array}$ \\
\hline c2 & $\begin{array}{l}\text { Chaotic environment during } \\
\text { MoOSTs restricts sharing }\end{array}$ & $\begin{array}{l}\text { Training and sharing experiences through contact } \\
\text { time and interactions are restricted in MoOSTs } \\
\text { environment because they are usually temporary } \\
\text { and require large numbers of outsourced staff at } \\
\text { different locations in the plant. }\end{array}$ \\
\hline c3 & Limited job autonomy & $\begin{array}{c}\text { Organisations that limit capabilities of employees } \\
\text { to actively seek for problems and improvement } \\
\text { areas within systems can limit individual } \\
\text { learning experiences. }\end{array}$ \\
\hline
\end{tabular}


Table A9. Cont.

\begin{tabular}{|c|c|c|}
\hline Assigned Code & Hierarchy Elements & Brief Description of Hierarchy Elements \\
\hline c4 & Restricted information flow & $\begin{array}{c}\text { Bureaucratic and multilayered reporting } \\
\text { organisations' structure restricts information flow } \\
\text { and limits sharing. }\end{array}$ \\
\hline c5 & $\begin{array}{l}\text { Lack of leadership direction in } \\
\text { championing values } \\
\text { encouraging sharing }\end{array}$ & $\begin{array}{l}\text { Absence of leadership strategies to implement } \\
\text { and sustain sharing values can hamper } \\
\text { employees' willingness to adapt. }\end{array}$ \\
\hline c6 & Lack of a reward system & $\begin{array}{l}\text { Organisations that do not offer incentives (which } \\
\text { can be reflected in performance score cards, } \\
\text { job security, etc.) to employees for sharing their } \\
\text { experiences and or information. }\end{array}$ \\
\hline c7 & Individualism is unduly encouraged & $\begin{array}{l}\text { Organisations that encourage overtly competitive } \\
\text { individuals rather than team building capacities } \\
\text { when solving problems limit uptake of } \\
\text { employees that are willing to share. }\end{array}$ \\
\hline c8 & $\begin{array}{l}\text { Knowledge retention of experienced } \\
\text { staff is not prioritised }\end{array}$ & $\begin{array}{l}\text { Organisations that do not recognise experienced } \\
\text { employees as valuable assets in order to actively } \\
\text { pursue efforts that promote acquisition, } \\
\text { conversion, and diffusion of tacit to explicit } \\
\text { knowledge during and after MoOSTs. }\end{array}$ \\
\hline $\mathrm{d} 1$ & $\begin{array}{l}\text { Inability to integrate with other } \\
\text { processes }\end{array}$ & $\begin{array}{l}\text { Installation of IT systems for MoOSTs activities } \\
\text { have to be properly integrated into routine } \\
\text { processes or it might limit employees' } \\
\text { interactions such IT systems. }\end{array}$ \\
\hline $\mathrm{d} 2$ & $\begin{array}{l}\text { Lack of compatibility between } \\
\text { diverse IT systems and processes }\end{array}$ & $\begin{array}{l}\text { Organisations sometimes succumb to popular } \\
\text { trends and acquire IT systems without } \\
\text { thoroughly assessing the requirements and } \\
\text { capabilities of their existing operational activities. }\end{array}$ \\
\hline $\mathrm{d} 3$ & Lack of technical support & $\begin{array}{l}\text { The inability of organisations to dedicate } \\
\text { resources to respond to active queries within the } \\
\text { IT system can limit the willingness of employees } \\
\text { to interact with such systems. }\end{array}$ \\
\hline $\mathrm{d} 4$ & Lack of employees' interest & $\begin{array}{l}\text { Employees who are not interested or motivated } \\
\text { to use available IT systems due to the inability of } \\
\text { their organisations to convince them on the } \\
\text { intrinsic and extrinsic values such systems } \\
\text { possess. }\end{array}$ \\
\hline d5 & $\begin{array}{c}\text { Lack of adequate training and } \\
\text { development }\end{array}$ & $\begin{array}{l}\text { Inability to allocate time and resources to train } \\
\text { employees on different IT systems. }\end{array}$ \\
\hline d6 & $\begin{array}{l}\text { Unrealistic expectations of } \\
\text { capabilities of IT systems by users }\end{array}$ & $\begin{array}{l}\text { Limited information on the capabilities of } \\
\text { existing IT systems can lead to employees having } \\
\text { unrealistic expectations of what such systems can } \\
\text { and cannot do, which can lead to } \\
\text { disappointments and unwillingness to interact } \\
\text { further with the system. }\end{array}$ \\
\hline
\end{tabular}




\section{Appendix D}

Table A10. Group decision participants profiles and categories.

\begin{tabular}{|c|c|c|c|}
\hline Participants Job Title & Sample Size & MoOSTs Responsibility & Category \\
\hline Maintenance manager & 1 & \multirow{4}{*}{$\begin{array}{l}\text { Middle to senior management staff directly } \\
\text { involved with MoOSTs, who makes/approves } \\
\text { decisions on overall strategies. }\end{array}$} & \multirow{4}{*}{ A } \\
\hline Reliability manager & 1 & & \\
\hline $\begin{array}{l}\text { Health, safety, } \\
\text { and environment manager }\end{array}$ & 1 & & \\
\hline $\begin{array}{c}\text { Contracts and purchasing } \\
\text { manager }\end{array}$ & 1 & & \\
\hline Maintenance planner & 1 & \multirow{4}{*}{$\begin{array}{l}\text { Supervisory staff involved with the } \\
\text { implementation of engineering methods and/or } \\
\text { techniques, who also has authority to make } \\
\text { decisions during MoOSTs. }\end{array}$} & \multirow{4}{*}{ B } \\
\hline Shutdown executioner & 1 & & \\
\hline Cost controller & 1 & & \\
\hline Document controller & 1 & & \\
\hline Maintenance technician & 2 & $\begin{array}{c}\text { Shop floor staff experienced with handling } \\
\text { plant assets and schematics showing working } \\
\text { of the plant. }\end{array}$ & $\mathrm{C}$ \\
\hline
\end{tabular}

\section{References}

1. Gold, A.H.; Malhotra, A.; Segars, A.H. Knowledge Management: An Organizational Capabilities Perspective. J. Manag. Inf. Syst. 2001, 18, 185-214. [CrossRef]

2. Refaiy, M.; Labib, A. The effect of applying tacit knowledge on maintenance performance: An empirical study of the energy sector in the UK and Arab countries. Knowl. Manag. Res. Pract. 2009, 7, 277-288. [CrossRef]

3. Riege, A. Three-dozen knowledge-sharing barriers managers must consider. J. Knowl. Manag. 2005, 9, 18-35. [CrossRef]

4. Elwerfalli, A.; Khan, M.K.; Munive-Hernandez, J.E. Developing Turnaround Maintenance (TAM) Model to Optimise TAM Performance Based on the Critical Static Equipment (CSE) Of GAS Plants. Int. J. Ind. Eng. Oper. Manag. 2018, 1, 12-31.

5. Elemnifi, S.M.; Elfeituri, F. Optimizing Turnaround Maintenance Performance. In Proceedings of the Eighth Pan-Pacific Conference on Occupational Ergonomics, Bangkok, Thailand, 17-19 October 2007.

6. Fabić, M.; Pavletić, D.; Soković, M. Consideration of Factors in Turnaround Refinery (Tar) Project Management. Int. J. Adv. Qual. 2017, 44, 35. [CrossRef]

7. Bevilacqua, M.; Ciarapica, F.E.; Giacchetta, G.; Marchetti, B. Development of an innovative criticality index for turnaround management in an oil refinery. Int. J. Prod. Qual. Manag. 2012, 9, 519. [CrossRef]

8. Ertl, B. Applying PMBOK to Shutdowns, Turnarounds and Outages; Republished with permission (Plant Maintenance Resource Centre); Turnarounds Outages Inter Plan Systems Inc.: Paris, France, 2005.

9. Levitt, J. Managing Maintenance Shutdowns and Outages; Industrial Pr Inc.: Los Angeles, CA, USA, 2004.

10. Bresnen, M.; Edelman, L.; Newell, S.; Scarbrough, H.; Swan, J. Social practices and the management of knowledge in project environments. Int. J. Proj. Manag. 2003, 21, 157-166. [CrossRef]

11. Tranfield, D.; Denyer, D.; Marcos, J.; Burr, M. Co-producing management knowledge. Manag. Decis. 2004, 42, 375-386. [CrossRef]

12. Syed-Ikhsan, S.O.S.; Rowland, F. Knowledge management in a public organization: A study on the relationship between organizational elements and the performance of knowledge transfer. J. Knowl. Manag. 2004, 8, 95-111. [CrossRef]

13. Al-Alawi, A.I.; Al-Marzooqi, N.Y.; Mohammed, Y.F. Organizational culture and knowledge sharing: Critical success factors. J. Knowl. Manag. 2007, 11, 22-42. [CrossRef]

14. Al-Turki, U.; Duffuaa, S.; Bendaya, M. Trends in turnaround maintenance planning: Literature review. J. Qual. Maint. Eng. 2019, 25, 253-271. [CrossRef]

15. Parsa, K.; Torfi, F. International Journal of Economics and Financial Issues Implementation Multi-criteria Decision Making Technique in Overhaul Power Plants Projects. Int. J. Econ. Financ. Issues 2016, 6, 11-13. 
16. Hadidi, L.; Khater, M.A. Loss prevention in turnaround maintenance projects by selecting contractors based on safety criteria using the analytic hierarchy process (AHP). J. Loss Prev. Process. Ind. 2015, 34, 115-126. [CrossRef]

17. Duffuaa, S.O.; Hadidi, L. Using QFD to Conduct Performance Assessment for Turnaround Maintenance in Petrochemical Infrastructure. J. Infrastruct. Syst. 2017, 23. [CrossRef]

18. Madsen, P.M.; Desai, V. Failing to Learn? The Effects of Failure and Success on Organizational Learning in the Global Orbital Launch Vehicle Industry. Acad. Manag. J. 2010, 53, 451-476. [CrossRef]

19. Haunschild, P.R.; Sullivan, B. Learning from Complexity: Effects of Prior Accidents and Incidents on Airlines' Learning. Adm. Sci. Q. 2002, 47, 609-643. [CrossRef]

20. Yunusa-Kaltungo, A.; Kermani, M.M.; Labib, A. Investigation of critical failures using root cause analysis methods: Case study of ASH cement PLC. Eng. Fail. Anal. 2017, 73, 25-45. [CrossRef]

21. Labib, A.; Harris, M. Learning how to learn from failures: The Fukushima nuclear disaster. Eng. Fail. Anal. 2015, 47, 117-128. [CrossRef]

22. Yunusa-Kaltungo, A.; Labib, A. A hybrid of industrial maintenance decision making grids. Prod. Plan. Control 2020, 1-18. [CrossRef]

23. Labib, A.; Read, M. A hybrid model for learning from failures: The Hurricane Katrina disaster. Expert Syst. Appl. 2015, 42, 7869-7881. [CrossRef]

24. Vidal, L.-A.; Marle, F.; Bocquet, J.-C. Using a Delphi process and the Analytic Hierarchy Process (AHP) to evaluate the complexity of projects. Expert Syst. Appl. 2011, 38, 5388-5405. [CrossRef]

25. Okoli, C.; Pawlowski, S.D. The Delphi method as a research tool: An example, design considerations and applications. Inf. Manag. 2004, 42, 15-29. [CrossRef]

26. Stephen, C.; Labib, A. A hybrid model for learning from failures. Expert Syst. Appl. 2018, 93, $212-222$. [CrossRef]

27. Baig, A.A.; Ruzli, R.; Buang, A.B. Reliability Analysis Using Fault Tree Analysis: A Review. Int. J. Chem. Eng. Appl. 2013, 4, 169-173. [CrossRef]

28. Zhao, X.M. Research on FTA of Fire and Explosion in the Crude Oil Gatheringtransport Combination Station. Procedia Eng. 2011, 11, 575-582. [CrossRef]

29. Volkanovski, A.; Čepin, M.; Mavko, B. Application of the fault tree analysis for assessment of power system reliability. Reliab. Eng. Syst. Saf. 2009, 94, 1116-1127. [CrossRef]

30. Ahmed, A.; Kayis, B.; Amornsawadwatana, S. A review of techniques for risk management in projects. Benchmarking Int. J. 2007, 14, 22-36. [CrossRef]

31. Bourouni, K. Availability assessment of a reverse osmosis plant: Comparison between Reliability Block Diagram and Fault Tree Analysis Methods. Desalination 2013, 313, 66-76. [CrossRef]

32. Distefano, S.; Puliafito, A. Dynamic Reliability Block Diagrams VS Dynamic Fault Trees. In Proceedings of the 2007 Annual Reliability and Maintainability Symposium, Orlando, FL, USA, 22-25 January 2007; pp. 71-76.

33. Shahin, A.; Mahbod, M.A. Prioritization of key performance indicators. Int. J. Prod. Perform. Manag. 2007, 56, 226-240. [CrossRef]

34. Vidal, L.-A.; Marle, F.; Bocquet, J.-C. Measuring project complexity using the Analytic Hierarchy Process. Int. J. Proj. Manag. 2011, 29, 718-727. [CrossRef]

35. Al-Harbi, K.M.-S. Application of the AHP in project management. Int. J. Proj. Manag. 2001, 19, $19-27$. [CrossRef]

36. Saaty, T.L. Decision making with the analytic hierarchy process. Int. J. Serv. Sci. 2008, 1, 83. [CrossRef]

37. Saaty, T.L. A scaling method for priorities in hierarchical structures. J. Math. Psychol. 1977, 15, $234-281$. [CrossRef]

38. Saaty, T.L. How to make a decision: The analytic hierarchy process. Eur. J. Oper. Res. 1990, 48, 9-26. [CrossRef]

39. Vargas, L.G. Reciprocal matrices with random coefficients. Math. Model. 1982, 3, 69-81. [CrossRef]

40. Wind, Y.; Saaty, T.L. Marketing Applications of the Analytic Hierarchy Process. Manag. Sci. 1980, 26, 641-658. [CrossRef]

41. Skulmoski, G.; Hartman, F.T.; Krahn, J. The Delphi Method for Graduate Research. J. Inf. Technol. Educ. Res. 2007, 6, 1-21. [CrossRef] 
42. Schmidt, R.; Lyytinen, K.; Keil, M.; Cule, P. Identifying Software Project Risks: An International Delphi Study. J. Manag. Inf. Syst. 2001, 17, 5-36. [CrossRef]

43. Yi, J. A measure of knowledge sharing behavior: Scale development and validation. Knowl. Manag. Res. Pr. 2009, 7, 65-81. [CrossRef]

44. Cabrera, A.; Collins, W.C.; Salgado, J.F. Determinants of individual engagement in knowledge sharing. Int. J. Hum. Resour. Manag. 2006, 17, 245-264. [CrossRef]

45. Matzler, K.; Renzl, B.; Mooradian, T.; Von Krogh, G.; Mueller, J. Personality traits, affective commitment, documentation of knowledge, and knowledge sharing. Int. J. Hum. Resour. Manag. 2011, 22, 296-310. [CrossRef]

46. Godbout, A.J. Managing core competencies: The impact of knowledge management on human resources practices in leading-edge organizations. Knowl. Process Manag. 2000, 7, 76-86. [CrossRef]

47. Cabrera, E.F.; Cabrera, A. Fostering knowledge sharing through people management practices. Int. J. Hum. Resour. Manag. 2005, 16, 720-735. [CrossRef]

48. Cheung, C.M.; Yunusa-Kaltungo, A.; Ejohwomu, O.; Zhang, R.P. Learning from Failures (LFF); Construction Health and Safety in Developing Countries; Taylor \& Francis: Abingdon, UK, 2019; pp. 205-217.

49. Luwei, K.C.; Yunusa-Kaltungo, A.; Sha'Aban, Y. Integrated Fault Detection Framework for Classifying Rotating Machine Faults Using Frequency Domain Data Fusion and Artificial Neural Networks. Machines 2018, 6, 59. [CrossRef]

50. Yunusa-Kaltungo, A.; Sinha, J. Condition Monitoring: A Simple and Practical Approach; LAP Lambert; Academic Publishing: Cambridge, MA, USA, 2012.

(C) 2020 by the authors. Licensee MDPI, Basel, Switzerland. This article is an open access article distributed under the terms and conditions of the Creative Commons Attribution (CC BY) license (http://creativecommons.org/licenses/by/4.0/). 